\title{
Antecedents and outcomes of satisfaction in buyer-supplier relationships in South Africa: A replication study
}

\begin{tabular}{|c|c|}
\hline \multicolumn{2}{|c|}{$\begin{array}{l}\text { Mornay Roberts-Lombard }{ }^{1} \text { (1) } \\
\text { Mercy Mpinganjira }^{1} \text { (1) } \\
\text { Göran Svensson }{ }^{1,2} \text { (1) }\end{array}$} \\
\hline \multirow{2}{*}{\multicolumn{2}{|c|}{$\begin{array}{l}\text { Affiliations: } \\
{ }^{1} \text { Department of Marketing } \\
\text { Management, University of } \\
\text { Johannesburg, South Africa }\end{array}$}} \\
\hline & \\
\hline \multicolumn{2}{|c|}{$\begin{array}{l}\text { Department of Marketing, } \\
\text { Kristiania University College, } \\
\text { Norway }\end{array}$} \\
\hline \multicolumn{2}{|c|}{$\begin{array}{l}\text { Corresponding author: } \\
\text { Mornay Roberts-Lombard, } \\
\text { mornayrl@uj.ac.za }\end{array}$} \\
\hline \multicolumn{2}{|c|}{$\begin{array}{l}\text { Received: } 09 \text { Nov. } 2015 \\
\text { Accepted: } 26 \text { May } 2017 \\
\text { Published: } 27 \text { Oct. } 2017\end{array}$} \\
\hline \multicolumn{2}{|c|}{$\begin{array}{l}\text { How to cite this article: } \\
\text { Roberts-Lombard, M., } \\
\text { Mpinganjira, M. \& Svensson, } \\
\text { G., 2017, 'Antecedents and } \\
\text { outcomes of satisfaction in } \\
\text { buyer-supplier relationships } \\
\text { in South Africa: A replication } \\
\text { study', South African Journal } \\
\text { of Economic and Management } \\
\text { Sciences 20(1), a1497. https:// } \\
\text { doi.org/10.4102/sajems. } \\
\text { v20i1.1497 }\end{array}$} \\
\hline \multicolumn{2}{|c|}{$\begin{array}{l}\text { Copyright: } \\
\text { (c) 2017. The Authors. } \\
\text { Licensee: AOSIS. This worl } \\
\text { is licensed under the } \\
\text { Creative Commons } \\
\text { Attribution License. }\end{array}$} \\
\hline \multicolumn{2}{|l|}{ Read online: } \\
\hline 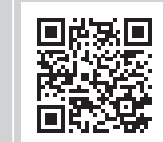 & $\begin{array}{l}\text { Scan this QR } \\
\text { code with your } \\
\text { smart phone or } \\
\text { mobile device } \\
\text { to read online. }\end{array}$ \\
\hline
\end{tabular}

Background: There is a clear difference of opinion amongst researchers on the interrelatedness of the variables trust, commitment, satisfaction, coordination, cooperation and continuity in a business-to-business (B2B) environment. The reason is that in previous studies much emphasis has been placed on creating and testing new theories, and not on providing practical generalities.

Aim: The aim of this study was to determine how the variable satisfaction is positioned in relation to trust and commitment, and how satisfaction relates to the variables coordination, cooperation and continuity in a South African B2B environment.

Setting: This study replicates a similar study conducted in 2013 in a B2B environment in South Africa and hopes to validate the outcome of that study by determining the relationship between the constructs postulated in the current study. The relationships between the different constructs in the proposed model will, therefore, provide a longitudinal perspective which is unique in terms of B2B research in South Africa.

Methods: Both the original and replication studies followed a quantitative approach and targeted large companies in South Africa. In the original study, data were collected from 500 large South African companies, while in the replication study data were collected from 250 large companies. Structural equation modelling was used to analyse the data.

Results: The findings specifically point to the need for organisations to direct resources towards the establishment of relationships that are founded on trust and commitment. Doing so will help ensure increased satisfaction, which, in turn, will result in greater coordination and cooperation in B2B relationships as well as long-term continuation of the relationship.

Conclusion: The foundation for strong B2B relationships is to secure customer satisfaction. Business managers ought to understand that when business customers are dissatisfied, it can result in the discontinuation of the business relationship.

\section{Introduction}

The literature on relationship marketing proposes that a business focused on the establishment of relationships with their customers has a long-term orientation that is founded on continuity. The employees of a business that understands the theory of relationship marketing will be more inclined towards a long-term orientation for the retention of existing customers (Ndubisi et al. 2016:373). Considering this, the growing competition in the business environment has resulted in a renewal of interest in business-to-business (B2B) relationship marketing. This is because the development of strong relationships between buyers and suppliers is known to contribute significantly to business by reducing risks in exchange relations (Segarra-Moliner, Moliner-Tena and Sánchez-Garcia 2013:196-197). Researchers such as Segarra-Moliner et al. (2013), Vesel and Zabkar (2010), Skarmeas et al. (2008) and Morgan and Hunt (1994) have highlighted the importance of elements such as trust, commitment and satisfaction in the relationship-building process. Nevertheless, researchers do not agree on how these three concepts relate to each other.

Kundu and Datta (2015:23) state that satisfaction is an affirmative, emotional state that is the result of an assessment of all facets of the working relationship between parties. Han and Hyun (2015:20) stipulate that the level of trust that a customer has in a business, will have a direct influence on its level of satisfaction expectation, which ultimately will influence its satisfaction experience. Salleh (2016:184), Kashif et al. (2015:28) and Taylor, Donovan and Ishida (2014:129) concur by stating that trust is a critical factor in the creation of value to the customer and directly 
contributes to customer satisfaction. Bojei and Abu (2014:174) further contend that commitment is also an antecedent of satisfaction and argue that the more committed a customer is to a supplier, the higher the level is of satisfaction expectations. Chang et al. (2015:868) concur and argue that commitment is an important indicator of the strength of a relationship with a supplier and is driven by previous experiences of satisfaction.

Sanchez-Franco (2009:248) also argues that satisfaction can be perceived as an antecedent of both trust and commitment. Theron, Terblanche and Boshoff (2011:188) perceive satisfaction as a predictor of trust, while Hau and Ngo (2012:225) are of the opinion that trust generates satisfaction. Considering this, there is a clear difference of opinion amongst researchers on the interrelatedness of the variables trust, commitment and satisfaction. The reason is that in previous studies much emphasis has been placed on creating and testing new theories, and not on providing practical generalities (Geyskens, Steenkamp \& Kumar 1999:231).

Hair et al. (2010) address the relevance of validating the findings in the development of theory. Further, Hair Celsi et al. (2011:33) state that theory development is a cumulative process and that the validation in one study with another through findings is needed so as to develop valid and reliable theory. The substantiation of findings can, therefore, be performed through replication and/or pure validation studies. This argument is supported by Gummesson, Kuusela and Närvänen (2014:229-230) and Grönroos (2006:38-40) who argue that the focus of research in marketing is changing towards a stronger emphasis on marketing strategy with practical recommendations over a longer period of time. There is a movement away from studies that makes a onetime contribution towards longitudinal studies with definite substantiations and contributions (Skarmeas et al. 2008:33). Nyaga, Whipple and Lynch (2010:112) also argue that relationships build on two-way engagement are characterised by a long-term approach. Thus, a longitudinal study of the relationship approach between a buyer and a supplier might deliver different results from a pure cross-sectional study.

This study aims at determining the relationship between trust, commitment, satisfaction, coordination, cooperation and continuity in a South African B2B environment. The authors propose that satisfaction is an outcome of trust and commitment on the one hand, and an antecedent of coordination, cooperation and continuity on the other. The importance of this study is in the re-testing of the different relational constructs in the theoretical model within a South African B2B environment. Most studies on B2B relationships are based on findings of studies conducted in developed countries (e.g. Ata and Toker 2012; Ashnai et al. 2009; Gounaris 2005; Lages, Lancastre \& Lages 2008; Lamprinopoulou \& Tregear 2011; Ndubisi 2009). However, no study has previously been conducted to test the constructs in the proposed model, from a Social Exchange Theory (SET) and Relationship Marketing Theory (RMT) perspective in a developing market environment such as South Africa.
By testing the proposed model in a developing country context, this study contributes to literature by bringing findings from a geographical different context. In testing the proposed model, this study replicates a similar study ${ }^{1}$ conducted in a B2B environment in South Africa and hopes to validate the outcome of that study by determining the relationship between the constructs postulated in the current study. The relationships between the different constructs in the proposed model will, therefore, provide a longitudinal perspective, which is unique in terms of B2B research in South Africa. Keeping in mind that the business contextual factor is ever static over time ( $\mathrm{Hu}, \mathrm{Wu} \&$ Chen 2013:492) as competition tends to get stiffer with time and new business models may be adopted by some in order to ensure business success in the face of changing business environment. The present study will, thus, assist in uncovering if changes that have taken place in the South African business environment including growing levels of competition demands a relook at relationship-building strategies. This is specifically in relation to ensuring satisfaction, coordination, cooperation and continuity in business relationships.

The structure of the article is as follows. Firstly, a theoretical argument is provided for the development of the conceptual model proposed in the study and the related hypotheses. Secondly, a discussion on the methodology used and the data analysis and results follows. Lastly, the conclusions, limitations and implications are considered.

\section{Theoretical framework and hypotheses}

Figure 1 illustrates the conceptualised model proposed for this study. As shown in the figure, satisfaction is positioned as an outcome of trust and commitment and the precursor of cooperation, coordination and continuity. Figure 1 further indicates that all the paths are hypothesised to be positive. The following discussion provides a literature perspective in support of the formulated hypotheses.

\section{Theories grounding the study}

The study is founded on the principles of the SET and the RMT in relation to the constructs explored and the proposed relationships between the constructs. SET is founded on the principle of voluntary exchange of value between individuals (business-to-consumer) and organisations (B2B) in the relational process. As a result, it (SET) embraces the norm of mutual exchange, where value creation is to the benefit of all parties involved (Tanskanen 2015:579). SET further proposes that the building of relationships is founded on the basis of a subjective cost-benefit analysis as well as the evaluation of options (Liu et al. 2016:54). This implies that the parties to a relationship will evaluate the future of a relationship on the value that is still to be accrued from a partner (e.g. financial rewards, the trustworthiness of a partner and the level of future satisfaction from the relationship) (Sierra \&

1.Authors of previous study. The name of the authors of the original study cannot be provided as they are also involved in the duplication study. 


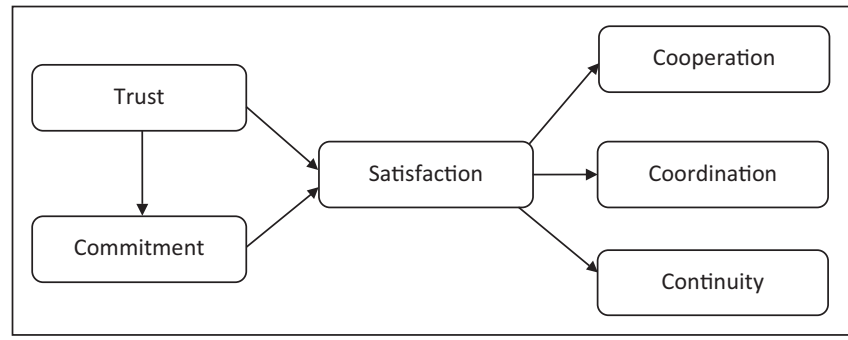

FIGURE 1: Conceptual model.

McQuitty 2005:393). Chen and Choi (2005:2) and Ward and Berno (2011:1557) concur and state that social exchange is not always founded on financial rewards, although the continuation of the relationship will be based on views regarding the comparative costs and benefits of the relationship, past experience of satisfaction and its implication(s) for future relationship satisfaction. Considering this, SET has been found to produce outcomes such as trust, informal commitment and satisfaction (Lawler 2001:326; Lioukas \& Reuer 2015:1826, 1829).

In terms of RMT, Stavros and Westberg (2009:308) and Lui, Wong and Liu (2009:1216) argue that relationship marketing embraces a customer-centric approach with the primary outcomes being increased customer retention, greater loyalty, lower marketing costs and increased profit levels. Ballantyne (2003:1255) argues that a relationship improvement strategy is initiated by the following question: 'What is of value and to whom?' Nicholson, Lindgreen and Kitchen (2009:195) state that the manner in which a relationship is managed by the parties involved will have a direct influence on a partner's perception of trust in the relationship, which ultimately will influence the level of commitment towards the continuation of the relationship. This is an argument that has been posited in the seminal work of Morgan and Hunt (1994) in their trustcommitment model, perceived as one of the most applied models in inter-organisational relationship-building in relationship marketing. Therefore, the theory of relationship marketing is founded on the principles of trust between parties, the cultivation of mutual understanding between such parties, the ability to deliver on expectations based on previous cooperative history, to eventually secure customer cooperation as an outcome (Chang et al. 2015:869-870).

Considering the discussion above, the authors draw on the foundations of these theories to hypothesise the relationships between the constructs of the study, in the South African B2B environment. No previous study in the context of the South African B2B environment has applied the SET or the RMT to propose that satisfaction is an outcome of trust and commitment on the one hand, and an antecedent of coordination, cooperation and continuity on the other.

\section{A relationship marketing approach to business- to-business markets}

The current, competitive business environment necessitates an understanding of the changing nature of B2B relationshipbuilding dynamics. The supplier no longer has the principal influence in the relationship because the buyer or customer is increasingly playing a key role in the establishment and management of relationship commitment and trust to secure satisfaction (Brodie 2017:22). Knox and Gruar (2007:115) concur and argue that RMT proposes the establishment and building of mutually beneficial value-add relationships between all relevant stakeholder groups, based on the principles of trust and commitment, to secure long-term satisfaction. RMT, therefore, argues that a continuous focus on customer relationship development secures the development of customer value strategies. Such strategies create a platform for the creation of a sustainable competitive advantage and increased profitability in the long-term (Theron \& Terblanche 2010:384).

Relationship marketing is perceived as an influential strategy for companies aiming to distinguish their product offerings in the market environment. It has also become a growing area of international research considering the globalisation of markets (Samaha, Beck \& Palmatier 2014:93). The supporters of the relationship marketing philosophy argue that business survival is no longer dependent on traditional marketing approaches of developing, selling and delivering products to customers without securing their retention for future purchases. Relationship marketing is encompassing a more inclusive focus that is founded on the establishment, growth and management of relationships that are both beneficial and satisfying to all parties involved (Leahy 2011:1). According to Malhotra, Uslay and Ndubisi (2008:213), relationship marketing is the foundation on which B2B relationships are built and is a growing area in the domain of business relationships. Theron and Terblanche (2010:386) also argue that the relevance of a relationship-orientated approach to marketing was highlighted in 2004 by the American Marketing Association (AMA) with the introduction of a new definition of marketing management:

Marketing is an organizational function and a set of processes for creating, communicating, and delivering value to customers and for managing customer relationships in ways that benefit the organization and its stakeholders. (Harker \& Egan 2006:217)

Sheth and Parvatiyar (1995:399) further posit that in a B2B relationship, it is key for all parties to secure elevated levels of satisfaction with every single business interaction.

The key focus of a relationship marketing strategy is, therefore, to establish relationships at all points of interface with the customer. The outcome of this should be to establish benefits for both the organisation and the customer (Theron \& Terblanche 2009:384). Managing B2B relationships is intricate because these relationships are often close, complex and long-term (Sarmento, Simões \& Farhangmehr 2015:131). Therefore, an understanding of the management of B2B relationships can be attained once clarity has been obtained on the different elements contributing to them (Theron, Terblanche \& Boshoff 2010:198). In the marketing literature, there is wide recognition of the importance of trust, commitment and satisfaction in the relationship-building 
process (Brito, Brito \& Hashiba 2014; Jarratt \& Ceric 2015; Ndubisi 2011; Morgan \& Hunt 1994).

Table 1 serves as a support for this statement reflecting current studies on trust, commitment and satisfaction and why trust is an antecedent of commitment.

Altinay et al. (2014:724) and Laeequddin et al. (2012:551-552) state that in a buyer-seller relationship, trust is perceived as a key element in the relationship-building process. If the level of trust between partners is perceived as high, the willingness to commit to such a relationship is also stronger, eventually leading to higher levels of satisfaction. Despite this, there is limited knowledge on how to manage $\mathrm{B} 2 \mathrm{~B}$ relationships from a comprehensive perspective to secure positive relationship-building with the outcome of coordination, cooperation and continuity. The reason for including coordination, cooperation and continuity as outcome variables of interest in this study is that they are key characteristics of strong relationships in B2B marketing (Payan et al. 2016:64; Razzaque \& Boon 2003:
30-31; Shamdasani \& Sheth 1995:8-9; Theron \& Terblanche 2010:389-390). RMT argues that strong exchange relations are key to business success ( $\mathrm{Ng}$ 2012:161; Wilson \& Nielson 2001:3). According to Chang and Chuang (2016:519), cooperation represents an engaging process whereby the buyer actively interacts with the product innovation processes of the supplier to drive participation. Satisfied engagement experiences, therefore, become a driver for further cooperation between a buyer and a supplier. Coordination reflects engagement in joint activities relating to structure or process, between organisations (Keung et al. 2015:1). Coordination is key to ensuring high levels of efficiency and achievement of objectives in B2B relations. It helps to reduce conflict and disagreements, thereby ensuring smooth working relations. Continuity, on the other hand, is concerned with the duration of the business relationship. Success in relationship marketing is therefore characterised by loyalty, which includes commitment to continued business relations (Gaurav 2016:5). The various constructs depicted in Figure 1 form the focal point of this article, and different hypotheses are formulated that relate to these constructs.

TABLE 1: Current research on the topics of trust, commitment and satisfaction.

\begin{tabular}{|c|c|c|}
\hline Variable & Key premise & Reference \\
\hline \multirow[t]{8}{*}{ Trust } & $\begin{array}{l}\text { Both trust and satisfaction are positively related to commitment. The greater the level of trust between partners, } \\
\text { the higher the commitment is and the greater the opportunity to secure satisfaction as a positive outcome. }\end{array}$ & Macintosh (2002) \\
\hline & $\begin{array}{l}\text { The building of long-term relationships is based on trust and commitment. When a higher level of trust is } \\
\text { established between two parties in a relationship, increased levels of both commitment and retention are } \\
\text { experienced. }\end{array}$ & Read (2009) \\
\hline & $\begin{array}{l}\text { An organisation must build relationships with customers that are built on the principle of trust through the } \\
\text { delivery of a high-quality product or service offering. This will ensure increased customer satisfaction, resulting in } \\
\text { a higher level of commitment. }\end{array}$ & Negi and Ketema (2010) \\
\hline & $\begin{array}{l}\text { Trust is a fundamental tool in the creation and establishment of long-term relationships because without trust, } \\
\text { commitment cannot be secured. }\end{array}$ & Ndubisi (2011) \\
\hline & $\begin{array}{l}\text { The literature overwhelmingly supports the application of trust as a central element in the building and } \\
\text { management of relationships in a B2B and B2C environment. }\end{array}$ & Theron, Terblanche and Boshoff (2012) \\
\hline & $\begin{array}{l}\text { A critical element in the relationship-building process is the element of trust. The reason is that parties to a } \\
\text { relationship regard trust so highly that they will commit themselves to a relationship if trust is present. }\end{array}$ & Jumaev, Kumar and Hanaysha (2012) \\
\hline & Trust is perceived as a key antecedent of commitment, satisfaction and customer retention. & Fang et al. (2014) \\
\hline & Trust is a prerequisite for positive relational exchanges. & Jarratt and Ceric (2015) \\
\hline \multirow{8}{*}{ Commitment } & $\begin{array}{l}\text { Increased levels of customer commitment are influenced by the customer's belief that he or she has received } \\
\text { greater levels of value and satisfaction from a relationship. }\end{array}$ & Wong and Zhou (2006) \\
\hline & Both trust and commitment function as important antecedents to satisfaction as an outcome of a relationship. & Nyaga et al. (2010) \\
\hline & $\begin{array}{l}\text { Higher levels of trust in B2B relationships enhance the level of commitment between the parties. This secures an } \\
\text { increased willingness to cooperate and work together for the long-term benefit of all parties concerned. }\end{array}$ & Voldnes, Grønhaug and Nilssen (2012) \\
\hline & Shared commitment is a prerequisite for the establishment of long-term relationships. & Rai and Medha (2013) \\
\hline & The variables trust, satisfaction and commitment are key to securing the loyalty of customers in the long-term. & Sarmento et al. (2015) \\
\hline & Commitment mirrors the continuous need for an individual to retain the relationship with the organisation. & Chiu, Kwag and Bae (2015) \\
\hline & $\begin{array}{l}\text { The attitude of a customer towards the value received from an organisation depends on the quality of the } \\
\text { relationship experienced with that organisation, which is based on elements such as customer satisfaction, trust } \\
\text { and commitment. }\end{array}$ & Purnasaria and Yuliandoa (2015) \\
\hline & Commitment has a close relationship with trust resulting in a willingness to continue with the relationship. & Kuhn and Mostert (2016) \\
\hline \multirow[t]{7}{*}{ Satisfaction } & $\begin{array}{l}\text { Satisfaction is a key element in the relationship management process and influences the willingness of all parties } \\
\text { to have a long-term orientation to the relationship. }\end{array}$ & Geyskens et al. (1999) \\
\hline & $\begin{array}{l}\text { Satisfaction is the outcome of a relationship between two parties in a B2B or B2C environment. Trust is } \\
\text { positioned as a precursor to satisfaction in a buyer-seller relationship. }\end{array}$ & $\begin{array}{l}\text { Rodríguez-del-Bosque, Agudo and } \\
\text { Gutiérrez (2006) }\end{array}$ \\
\hline & $\begin{array}{l}\text { The customers of an organisation choose the supplier that they can trust to do business with, thereby developing } \\
\text { their level of satisfaction. Trust is perceived as a central element to any buyer-supplier relational strategy. }\end{array}$ & Denga et al. (2010) \\
\hline & $\begin{array}{l}\text { Customer satisfaction based on trust enhances customer re-purchase intention, increasing organisational } \\
\text { profitability in the long-term. }\end{array}$ & Yeung et al. (2013) \\
\hline & Trust is a key contributor to satisfaction. & Altinay et al. (2014) \\
\hline & Trust and commitment are key to securing satisfaction, and the latter is central to ensuring customer loyalty. & Human and Naudé (2014) \\
\hline & $\begin{array}{l}\text { Satisfaction is that part of the buyer-supplier relational experience where the parties decide to continue with the } \\
\text { relationship or not. }\end{array}$ & Clampit et al. (2015) \\
\hline
\end{tabular}




\section{The relationship between trust and satisfaction}

Rauyruen and Miller (2007:24) state that trust is a key component in the relationship-building process when companies make promises to customers and then keep to their promises as well. Wang et al. (2014:1) emphasise that the increased acknowledgement of relationship marketing in the buyer-supplier relationship-building process has enhanced interest in the area of buyer trust. From a B2B perspective, trust is perceived as the degree to which a company views a business partner as being honest. Trust is also considered as the conviction of one partner that the other partner will conduct business that will secure positive benefits to the company and not conduct activities that will create a negative outcome to the business relationship (Hung, Cheng \& Chen 2012:667).

According to Fullerton (2011:95), the willingness of one party in a relationship to be associated with another will be guided by the principle of shared values such as trust. Laeequddin and Sardana (2010:355-356) concur and argue that a partner's level of satisfaction with a relationship will be influenced by previous engagements based on trust expectations. Satisfaction with previous experiences will influence the trust expectation of one partner to another in the $\mathrm{B} 2 \mathrm{~B}$ relationship, and the ultimate decision to continue or discontinue with the relationship (Sarmento et al. 2015:133). Voldnes et al. (2012:1082) confirm that trust is an antecedent of satisfaction because higher levels of trust between parties enhance overall satisfaction expectations and strengthen long-term commitment. Jiang, Henneberg and Naudé (2011:6) concur and state that trust is a primary precursor of satisfaction. They argue that when high levels of trust exist between the buyer and the seller, the former is usually satisfied with the relationship as there is trust that the activities of the supplier will secure positive results for all parties involved. This argument is further supported by Izogo (2016:377) who states that customers are more willing to be supportive of an organisation that establishes trust. Therefore, trust has a positive relationship with satisfaction.

Farrelly and Quester (2005:211) state that a customer with a strong trust in the supplier will expect the company to have open communication channels to enhance satisfaction experiences. Such open communication is critical in creating and sustaining positive buyer-supplier exchanges. Kaur, Sharma, and Mahajan (2012:282) concur and argue that buyers are more willing to continue with a relationship if the level of trust between the buyer and the seller is increased. This argument is further supported by Hansen, Morrow and Batista (2002:45) who state that satisfaction is a direct outcome of trust and increased levels of trust in the supplier can lead to higher levels of buyer satisfaction.

Considering the discussion above, it is argued that trust can be perceived as an antecedent to satisfaction. Therefore, the ensuing hypothesis is formulated:

$\mathbf{H}_{1}$ : Trust positively influences satisfaction.

\section{The relationship between commitment and satisfaction}

Commitment is seen as a key element in securing long-term $\mathrm{B} 2 \mathrm{~B}$ relationships. It is described as a partner's willingness to establish a long-term relationship with another partner and to continue with such an association, inclusive of an emotion of psychological attachment (Sung \& Choi 2010:1051). However, the level of commitment of a customer will depend on the customer's perception of the amount of effort that the seller puts into the relationship (Human \& Naudé 2014:921). Dai, Haried and Salam (2011:4) state that the growth of continuous exchange relationships with customers offers a supplier a customer base that secures reliable income. In the field of relationship marketing, the significance of establishing, developing and maintaining the commitment of the customer to the supplier is highlighted ( $\mathrm{Wu}, \mathrm{Zhou} \& \mathrm{Wu}$ 2012:1760). Kaur et al. (2012:285) and Theron and Terblanche (2010:388) state that the stronger the level of commitment becomes in a seller-buyer relationship, the more stable the relationship becomes. Espejel, Fandos and Flavián (2011:209) agree and propose that customer satisfaction is a direct outcome of buyer's commitment to the relationship with the seller, based on evaluating the difference between expectations and results. In addition, the commitment of employees towards the relationship-building initiatives of the supplier will strengthen customer relationship management initiatives, which could increase customer satisfaction levels (Ata \& Toker 2012:504). Kim (2014:2) also established that commitment has a substantial influence on customer satisfaction. This argument is supported by Richard and Zhang (2012:573) asserting that a satisfied buyer has a stronger commitment towards a supplier than an unsatisfied customer, which enhances loyalty in the long-term. Akman and Yörür (2012:220-221) concur and argue that a buyer will remain committed to the supplier if the former is satisfied with the value offered in the relationship. Therefore, a high level of commitment gives rise to increased satisfaction with the relationship. There is general agreement by some researchers in the field of relationship marketing that commitment can be perceived as an antecedent to satisfaction (Anderson \& Narus 1990; Johnson, Sividas \& Garbarino 2008; Mohr \& Spekman 1994; Wong \& Zhou 2006). Fullerton (2011:95) concur and state that satisfaction can only be secured if both parties are fully committed to the relationship. Therefore, committed can be perceived as an antecedent of satisfaction in a buyer-supplier relationship.

Morgan and Hunt (1994:22), in their seminal work on the trust-commitment theory, argue that commitment is central to the establishment and management of supplier-customer relationships. The reason is that it motivates customers not to consider short-term options as being more beneficial than the long-term opportunities that a relationship with an existing supplier might provide. Therefore, for the purpose of this study, commitment is defined as an 'implicit or explicit pledge of relational continuity between exchange partners', involving an 'enduring desire to maintain a valued relationship' (Sarmento et al. 2015:133). Rutherford (2012:961) 
also notes that a higher level of commitment towards a supplier can result in higher levels of customer satisfaction, a lower propensity by the buyer to spread negative word-ofmouth opinion, and lower levels of customer defection. Richard and Zang (2012:573) concur and state that the level of customer satisfaction experienced is determined by the level of commitment between a buyer and a seller. It is, therefore, theorised that commitment is an antecedent of customer satisfaction in $\mathrm{B} 2 \mathrm{~B}$ relationships:

$\mathbf{H}_{2}$ : Commitment positively influences satisfaction.

\section{Trust as an antecedent to commitment}

Hong and Cho (2011:473) and Hess et al. (2011:15) state that trust is a central element in buyer-supplier relationshipbuilding strategies. It is a key antecedent to commitment and is perceived as the most influential instrument available to a supplier in the relationship-building process. Hartmann, Klink and Simons (2015:110) support this argument by stating that a direct relationship exists between trust and commitment, because a higher level of trust between parties in a relationship implies greater commitment of one party to the other. Read (2009:27) also argues that a buyer will only commit to a trustworthy supplier as commitment involves vulnerability and could expose the buyer to opportunism. Nguyen and Mutum (2012:401-402) concur by arguing that trust is directly related to commitment because a buyer will be more willing to commit, if the supplier delivers on its promises and can, therefore, be trusted. The strengthening of customer commitment in a relationship can result in the buyer developing more trust in the supplier. Hung et al. (2012:667) further argue that when trust is formed between the buyer and the seller, there is a greater willingness to commit, securing a long-term orientation towards the relationship. This implies that being committed to a supplier is positively related to customer trust (Chang et al. 2012:942; Watkins \& Hill 2009:994).

Hasche, Linton and Öberg (2017:33) highlight the relationship between trust and commitment by stating that trust is a key construct influencing buyer commitment. These authors further state that the existence of trust between parties in a buyer-seller relationship implies a greater willingness between the parties to commit to the relationship. This will enable the parties to develop a relationship that goes beyond economic exchange and that could secure long-term partnering even when the economic benefits are no longer existing (Parra et al. 2011:608). Stein, Smith and Lancioni (2013:856) also note that the interrelatedness of the parties in a buyer-seller relationship will define their level of commitment and the eventual duration of the relationship. Morgan and Hunt (1994:23) state clearly that the major differentiation of these exchange relationship types ... is the mutual social trust and the resultant commitment on the part of the individuals to establish and maintain exchange relationships'. This argument by Morgan and Hunt (1994) supports the view proposed in this article that the construct trust is an antecedent to commitment. The following hypothesis is therefore formulated:

H3: Trust positively influences commitment.

\section{The relationship between satisfaction, cooperation, coordination and continuity}

Customer satisfaction has been a topic of research interest for academics over the past two decades (Akman \& Yörür 2012; Bejou, Ennew \& Palmer 1998; Bowden-Everson, Dagger \& Elliot 2013; Cheng et al. 2017; Garbarino \& Johnson 1999; Ndubisi 2012). A reason for this is the benefits that customer satisfaction holds for an organisation, such as relationship continuity and an increased willingness to remain with the organisation (Naumann, Williams \& Sajid Khan 2009). Since the early 1990s research has emphasised a shift in focus from a transactional to a relational approach towards relationship-building (Grönroos 1994; Morgan \& Hunt 1994; Sheth \& Parvatiyar 1995). This has resulted in customer satisfaction being identified as a key element in the development of relationship marketing strategies (Sun \& Kim 2013:68). In the context of this study, satisfaction is defined as 'a positive affective state resulting from the appraisal of all aspects of a firm's working relationship with another firm' (Sarmento et al. 2015:133). Satisfaction is largely acknowledged in the academic literature as an antecedent of behavioural outcomes such as customer retention (Trasorras, Weinstein \& Abratt 2009), customer loyalty (Bowen \& McCain 2015); Seto'-Pamies 2012) and word-of-mouth Ulaga and Eggert (2006). Satisfaction has also been identified as a key variable in the decision of a business to remain in a B2B relationship, where parties secure high levels of satisfaction during each business transaction (Sheth \& Parvatiyar 1995; Theron \& Terblanche 2010; Ulaga \& Eggert 2006). In addition, this study also hypothesises that cooperation, coordination and continuity are outcomes of satisfaction.

Biggemann and Buttle (2009:551) state that coordination in a relationship will be present when both parties understand the act of exchange, empowering them to believe that the establishment of interaction is a possibility. Skinner, Gassenheimer and Kelley (1992:180) concur by arguing that there is a positive relationship between satisfaction and cooperation and that cooperation can be an influential factor on the level of satisfaction experienced through a buyersupplier interaction. Mohr and Spekman (1994:139) also agree and state that the satisfaction of mutual expectations in the relationship strengthens the need for enhanced cooperation between parties. In terms of coordination, Guiltinan, Rejab and Rogers (1980:41) already argued in the beginning of the 1980's that coordination can only be secured if optimal system performance (inclusive of satisfaction) is secured. Mohr, Fisher and Nevin (1996:105) and Payan (2007:218) established that satisfaction is a precursor to coordination and the probability of continuity. This finding supports the illustration in Figure 1 showing that both coordination and continuity are proposed outcomes of satisfaction. The study further posits coordination as a behavioural outcome because of its conceptual similarity to both cooperation and continuity. Woodside and Baxter (2015:104) propose that in both new and established relationships, coordination through social bonding assists in 
strengthening the relationship, thereby securing its continuity expectancy. This argument is in line with the study of Palmatier et al. (2006:138-139) stating that satisfaction can be viewed as an antecedent to both coordination and continuity in the relationship-building process. Therefore, to strengthen relationship continuity through coordination and a positive satisfaction experience, both parties must illustrate a desire to continue with the relationship, the relationship must be important to both parties and it must provide a growing basis for personal and business satisfaction to the parties involved. Shamdasani and Sheth (1995:8) concur and state that the willingness of parties in a relationship to continue with the alliance depends on the level of satisfaction experienced with the partnership. Faryabi, Sadeghzadeh and Zakeri (2015:39) also agree and state that satisfaction is perceived as a direct influencer of the decision to continue with the relationship.

Therefore, for the purpose of this study, the concept 'continuity' relates to the duration of the relationship, and the communal undertakings by both parties are mirrored by coordination. In addition, the willingness of one party to work with the other will be the basis of cooperation (Evensen \& Hansen 2016; Faryabi et al. 2015; Samaha, Palmatier \& Dant 2011; Voldnes et al. 2012).

The academic argument proposed by this study is that the three outcomes of satisfaction, namely cooperation, coordination and continuity, are a reflection of the intent and actions that relate to the interactions between two organisations. Considering this, three hypotheses are formulated:

H4: Satisfaction positively influences coordination.

H5: Satisfaction positively influences continuity.

H6: Satisfaction positively influences cooperation.

\section{Methodology \\ Research context and samples}

When conducting research, one can take the cross-sectional time horizon or the longitudinal time horizon. The crosssectional time horizon data on variables of interest are collected only at a single point in time. The longitudinal time horizons involve collection to data with the purpose of observing the same variables over time to determine whether trends can be identified (Chisnall 2005). While in some longitudinal studies the same individuals serve as respondents over time, in business research, it is not always feasible to ensure that the same individual respondents take part in a study over time. This is because of varied reasons including movement of individuals to different positions or changes in company circumstances that make them fall out of the target population.

The target population of interest in this study was top companies in South Africa by revenue. Both the original and replication study followed a quantitative approach. The replication study was conducted in 2014/2015, while the original study was conducted in $2011 / 2012$. In both cases, a total of 500 largest companies in South Africa were included in the sample frame. This frame was derived from a Topco list of the top 500 companies operating in the private sector of South Africa, based on their turnover. The Topco list was chosen because it was the only list that provides details of all the top 500 companies in South Africa. Either the purchasing manager or the procurement manager was contacted by phone to establish the suitability of the respondent to answer the questionnaire. The reason for selecting the purchasing or procurement managers as respondents is that the study focused on business relationships with suppliers. Purchasing or procurement managers are the individuals who deal with suppliers in a company, which makes them more knowledgeable about relationship issues with their company suppliers. However, in a case where the respondent was not qualified to answer the questionnaire, another individual who was better qualified to answer was identified and used as a respondent. Computer-assisted telephone interviews were conducted with the respondents. Respondents were asked to keep one supplier that they were familiar with, in responding to the questions. In the current study, a total of 250 usable questionnaires were returned, which produced a response rate of $50.0 \%$. This compares well with the original study in which 232 usable questionnaires were returned, representing a response rate of $46.4 \%$.

Two items, namely, (1) how much the respondent knew about his or her company's perspective on the study topics and (2) how much the respondent knew about specific experiences with the supplier, were included for the purpose of checking the competency of the respondents used in both the original study and the replication study. This is in line with Campbell's (1955) recommendations that respondents used in a study need to be competent enough to answer questions relating to the subject matter under investigation. The findings of the original study and the replication study, respectively, showed that $96.6 \%$ and $94.8 \%$ of the respondents had knowledge of their company's perspective regarding the study topics and that $98.7 \%$ and $98.4 \%$ had knowledge regarding experiences with the supplier. The mean value for the first item in the original study was 4.24 and for the replication study it was 4.26. Regarding the second item, the mean value of the item in the original study was 4.31 and for the replication study it was 4.33. The mean values for both the original and replication studies illustrate that the respondents had appropriate knowledge about their company's perspective on the topics under study and their company's experiences with a supplier. The question on specific experiences with the supplier was aimed at capturing levels of knowledge through specific and not just general experiences with the supplier that the respondents considered when answering the questionnaire.

\section{Measures and scale items}

Measures that support the proposed conceptual model are depicted in Figure 1. Both the original and replication studies were based on exactly the same items used by 
Svensson, Mysen and Payan (2010) and others as discussed next. The choice to make use of pre-existing scales was because such scales help to enhance validity (Churchill 1979; Peter 1979). The items used to measure satisfaction were borrowed from the original work by Andaleeb (1996). Items used to measure commitment were borrowed from the original work by Morgan and Hunt (1994) and Anderson and Weitz (1992), while items used to measure trust were borrowed from the work of Zaheer, McEvily and Perrone (1998).

TABLE 2: Scale items: Original study and replication study.

\begin{tabular}{|c|c|}
\hline Variable & Item \\
\hline Trust & $\begin{array}{l}\text { a. This supplier is fair in its negotiations with us. } \\
\text { b. We can rely on this supplier to keep promises made to us. } \\
\text { c. This supplier is trustworthy. }\end{array}$ \\
\hline Commitment & $\begin{array}{l}\text { a. We would like to continue our work with this supplier. } \\
\text { b. We intend to do business with this supplier well into the future. } \\
\text { c. We are dedicated to continuing doing business with this supplier. }\end{array}$ \\
\hline Satisfaction & $\begin{array}{l}\text { a. Our firm is comfortable about its relationship with this supplier. } \\
\text { b. The relationship between this supplier and us is positive. } \\
\text { c. The relationship between this supplier and us is satisfying. }\end{array}$ \\
\hline Coordination & $\begin{array}{l}\text { a. Our implementation plans are formed jointly with this supplier. } \\
\text { b. We work jointly with this supplier on issues that affect } \\
\text { both firms. } \\
\text { c. Our processes and procedures are coordinated with those of } \\
\text { this supplier. }\end{array}$ \\
\hline Cooperation & $\begin{array}{l}\text { a. Our relationship with this supplier is cooperative. } \\
\text { b. There is a cooperative attitude between this supplier and us. } \\
\text { c. My firm prefers to cooperate with this supplier. }\end{array}$ \\
\hline Continuity & $\begin{array}{l}\text { a. We expect our relationship with this supplier to continue for } \\
\text { a long time. } \\
\text { b. Our relationship with this supplier is a long-term alliance. } \\
\text { c. Our relationship with this supplier is an alliance that is going } \\
\text { to last. }\end{array}$ \\
\hline
\end{tabular}

The items each to measure each of the proposed outcomes of satisfaction, namely, continuity, cooperation and coordination, were developed as follows: (1) continuity the items for this construct were borrowed from the work of Lusch and Brown (1996); (2) cooperation - the items for thisconstruct were borrowed from Skinner et al. (1992); and (3) coordination - the items for this construct were borrowed from the works of Guiltinan et al. (1980) and Heide and John (1988). A five-point Likert-type scale was used for all items in the original study and the replication study, using 'strongly agree' (5) and 'strongly disagree' (1) as the end points (refer to Table 2).

\section{Results \\ Measurement models}

The researchers used confirmatory factor analysis (CFA) and structural equation modelling (SEM) (Jöreskog \& Sörbom 1976) to test the measurement model and assess the structural relationships. Initially, the researchers performed CFAs of the measurement model (i.e. 18 indicator variables as in Figure 2) based upon six constructs, applying the SPSS/AMOS 22.0 software. Our testing of the model in the original study and the replication study generated consistent and satisfactory findings through time. The goodness-of-fit measures in the original study and the replication study were all acceptable (Hair et al. 2006:745-749), as shown in Table 3.

Results on testing of construct reliability and validity are presented in Table 4 for the original study and in Table 5 for

TABLE 3: Goodness-of-fit measures of the measurement model in the original and replication studies.

\begin{tabular}{lccccccccc}
\hline Study & CMIN & DF & P & CMIN/DF & NFI & IFI & TLI & CFI & RMSEA \\
\hline Original & 221112 & 120 & 0.00 & 1843 & 0.94 & 0.93 & 0.97 & 0.97 & 0.060 \\
Replication & 223869 & 120 & 0.00 & 1866 & 0.94 & 0.93 & 0.97 & 0.96 \\
\hline
\end{tabular}

CMIN, minimum value of the discrepancy; DF, degrees of freedom; P, p-value; CMIN/DF, minimum value of the discrepancy or the degrees of freedom; NFI, Normed Fit Index; IFI, Incremental Fit Index; TLI, Tucker-Lewis coefficient; CFI, Comparative Fit Index; RMSEA, root mean square error of approximation.

TABLE 4: Squared inter-construct correlations and summary statistics: Original study.

\begin{tabular}{|c|c|c|c|c|c|c|}
\hline Variable & Trust & Commitment & Cooperation & Coordination & Satisfaction & Continuity \\
\hline Trust & 1.000 & - & - & - & - & - \\
\hline Commitment & 0.50 & 1.000 & - & - & - & - \\
\hline Cooperation & 0.53 & 0.37 & 1.000 & - & - & - \\
\hline Coordination & 0.18 & 0.19 & 0.27 & 1.000 & - & - \\
\hline Satisfaction & 0.71 & 0.52 & 0.53 & 0.18 & 1.000 & - \\
\hline Continuity & 0.46 & 0.69 & 0.28 & 0.18 & 0.45 & 1.000 \\
\hline Variance extracted (\%) & 71 & 86 & 72 & 63 & 83 & 76 \\
\hline Composite trait reliability & 0.88 & 0.94 & 0.89 & 0.87 & 0.93 & 0.91 \\
\hline
\end{tabular}

TABLE 5: Squared inter-construct correlations and summary statistics: Replication study.

\begin{tabular}{|c|c|c|c|c|c|c|}
\hline Variable & Trust & Commitment & Cooperation & Coordination & Satisfaction & Continuity \\
\hline Trust & 1.000 & - & - & - & - & - \\
\hline Commitment & 0.72 & 1.000 & - & - & - & - \\
\hline Cooperation & 0.65 & 0.54 & 1.000 & - & - & - \\
\hline Coordination & 0.35 & 0.23 & 0.30 & 1.000 & - & - \\
\hline Satisfaction & 0.73 & 0.67 & 0.79 & 0.20 & 1.000 & - \\
\hline Continuity & 0.70 & 0.87 & 0.55 & 0.27 & 0.63 & 1.000 \\
\hline Composite trait reliability & 0.74 & 0.94 & 0.83 & 0.87 & 0.85 & 0.91 \\
\hline
\end{tabular}


the replication study. According to the results, the variance extracted from items of all constructs exceeds $50 \%$ in both the original study and replication study, which indicates convergent validity through time. The average explained variance is slightly higher in the original study $(75.2 \%)$ compared with the replication study $(68 / 2 \%)$. The composite trait reliability levels of all included constructs are also above 0.7 (Hair et al. 2006) in both the original study and the replication study.

Furthermore, the researchers compared the variance extracted to the squared inter-construct correlations to examine whether the model measures different constructs (Hair et al. 2006). In the original study, the variance extracted for all constructs was equal to or greater than the corresponding squared inter-construct correlations (see Table 4), while it was not greater for all constructs in the replication study (see Table 5). The reason is that the constructs were more strongly correlated to each other in

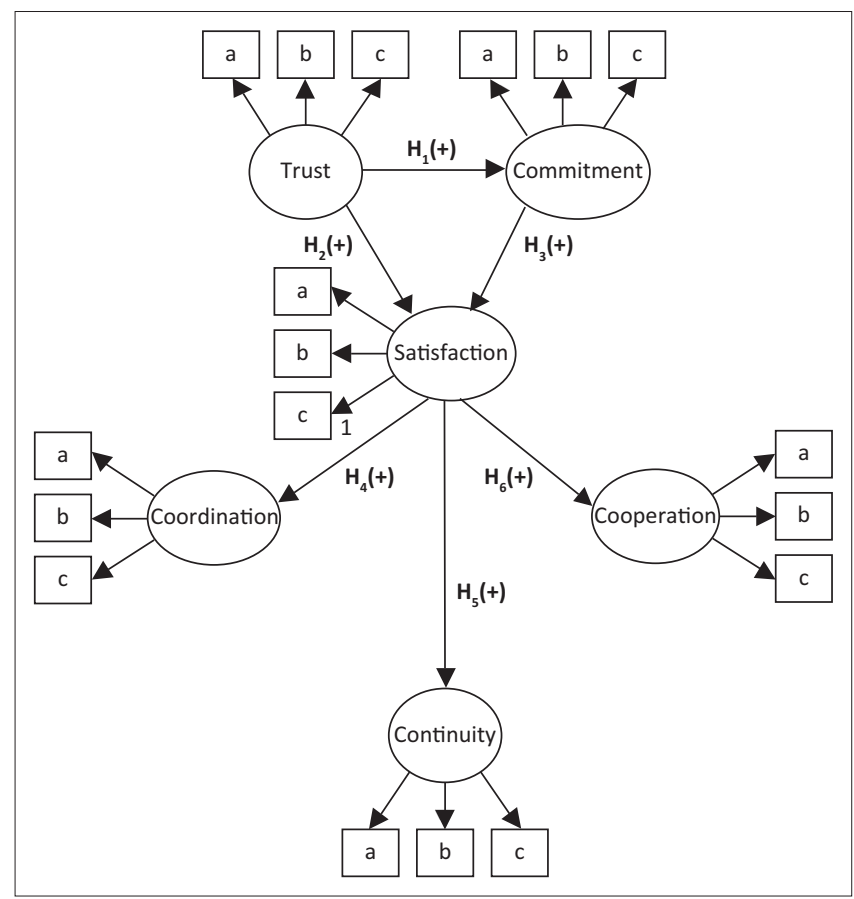

FIGURE 2: Six-construct structural model. the replication study than in the original one, which is a limitation. The researchers therefore argue that the tested structural model indicates satisfactory discriminant validity in the original study (see Figure 2), while it is less satisfactory in the replication study. The hypothesised relationships of the model were all significant in both the original study and the replication study as expected by theory, which indicates consistent and satisfactory nomological validity through time.

Our testing of the model in the original study and replication study based upon South African business relationships accomplishes satisfactorily the requirements for convergent and nomological validity, as well as for construct reliability. Discriminant validity between constructs is, however, not fully accomplished in the replication study because of stronger relationships between each of them. The researchers therefore conclude that the measurement and structural metrics of the model do not indicate full consistency of validity and reliability between the original study and the replication study.

\section{Structural models}

The researchers decided to test the structural model as illustrated in Figure 2 because of the satisfactory results from running the CFA of the measurement model in the original study and the replication study based on the South African business relationships.

The results of the goodness-of-fit measures of the structural model in the original study and the replication study are illustrated in Figure 2 (see Table 6). The results are consistent and satisfactory through time.

Furthermore, the structural model's hypothesised relationships (see Figure 2) were all significant in the original study and the replication study, as presented in Table 7. Accordingly, the results support consistently all six hypotheses of the model tested on South African business relationships in the original study and the replication study.

TABLE 6: Goodness-of-fit measures of the structural model.

\begin{tabular}{lccccccccc}
\hline Study & CMIN & DF & P & CMIN/DF & NFI & IFI & TLI & CFI & RMSEA \\
\hline Original study & 350316 & 129 & 0.000 & 2.716 & 0.91 & 0.94 & 0.93 \\
Replication study & 351474 & 129 & 0.000 & 2.725 & 0.91 & 0.94 & 0.93 \\
\hline
\end{tabular}

CMIN, minimum value of the discrepancy; DF, degrees of freedom; P, p-value; CMIN/DF, minimum value of the discrepancy or the degrees of freedom; NFI, (Normed Fit Index; IFI, Incremental Fit Index; TLI, Tucker-Lewis coefficient; CFI, Comparative Fit Index; RMSEA, root means square error of approximation.

TABLE 7: Tests of hypotheses.

\begin{tabular}{|c|c|c|c|c|c|c|}
\hline \multirow[t]{2}{*}{ Hypothesis } & \multirow[t]{2}{*}{ Exogenous construct } & \multirow[t]{2}{*}{ Endogenous construct } & \multicolumn{2}{|c|}{ Regression weight } & \multirow{2}{*}{$\begin{array}{l}\text { Significance - both } \\
\text { original and replication }\end{array}$} & \multirow[t]{2}{*}{ Finding } \\
\hline & & & Original & Replication & & \\
\hline 1 & Trust & Satisfaction & 0.659 & 0.546 & 0.000 & Supported \\
\hline 2 & Commitment & Satisfaction & 0.289 & 0.430 & 0.000 & Supported \\
\hline 3 & Trust & Commitment & 0.712 & 0.856 & 0.000 & Supported \\
\hline 4 & Satisfaction & Coordination & 0.466 & 0.543 & 0.000 & Supported \\
\hline 5 & Satisfaction & Continuity & 0.717 & 0.889 & 0.000 & Supported \\
\hline
\end{tabular}




\section{Managerial and theoretical implications}

Diverse contributions were made by this study to the domain of B2B relationship-building. Firstly, this study provided insights to guide organisations in an emerging economy on the different relationship marketing variables that should be included when developing relationship-building strategies. Different relationship marketing constructs (trust, commitment, satisfaction, cooperation, coordination and continuity) do influence buyer-supplier relational success and eventually the long-term survival of the organisation. It is also not often that the relationship marketing constructs of trust, commitment, satisfaction, coordination, cooperation and continuity are measured in a longitudinal study from an emerging market perspective.

Secondly, this study established that organisations operating in a B2B environment need to understand that the creation and establishment of long-term supplier-buyer relationships do not occur in a vacuum. The reason is that numerous variables could influence the durability of a relationship between two business partners (Chang et al. 2012:940; Segarra-Moliner et al. 2013:196). High levels of competition that characterise the South African business environment have a direct influence on the survival of organisations. This makes it imperative for business managers to identify and apply strategies aimed at enhancing their competitiveness so as to increase their business success (Saini, Bick \& Abdulla 2011:311; Theron \& Terblanche 2010:387). A strategy for business managers to consider is the creation of a positive working relationship with all role players in the value chain, which is supported by all parties in the relationship. This proposition is in line with the strategy recommendations of Ndubisi and Nataraajan (2016:228-229; Perez, Whitelock \& Florin 2013:434) whereby securing high-quality relationshipbuilding practices between parties should be a priority amongst business managers.

Thirdly, organisational success can be strengthened through the establishment of more intimate working relationships between partners in a B2B environment. Securing closer cooperation within the value chain is increasingly understood and supported by business managers in South Africa. This argument is supported by Crain and Abraham (2008), who state that:

a value-chain analysis helps a supplier distinguish between the activities of the customer's firm that directly support its competitive strategies - for its products and for enhancing key capabilities - and ordinary operations. (p. 33)

The business managers of corporate South Africa, therefore, need to create and develop a relational approach towards business partners that will enhance the value proposition to their respective organisations. This study established that to ensure that positive satisfaction is an outcome in the relationship-building process, greater attention must be paid to securing the establishment and strengthening of trust, and eventually commitment, in the relationship with a business partner. This argument is supported by Negi and Ketema (2010:114) and Jumaev et al. (2012:41), who hold that trust and commitment, as antecedents to customer satisfaction, are linked to and direct predictors of customer loyalty. Therefore, business managers must become more aware of the different aspects that influence satisfaction in a B2B relationship-building process. The findings that emanate from this study have indicated, as in the original study, that both trust and commitment, and not the one or the other, are critical elements in securing positive satisfaction. It is therefore important for managers to understand that the foundations of trust are threefold: that there should be fairness when engaged in negotiations with a business partner (i.e. they do not act unscrupulously towards the other to drive its own profit motive); that both parties to the relationship can be perceived as reliable, based on the promises made to each other; and that they can be perceived by each other as trustworthy. Furthermore, trust is strengthened when both parties to the relationship are convinced that they cater for the well-being of the other party. This can be ensured by determining exactly what the needs of each party are, having knowledge and understanding of the other party's expectations and making sure that all efforts are put in place to surpass such expectations. Che and Salleh (2016:184) concur by stating that trust is a critical element in the relationship-building process, where parties to the relationship have confidence in each other and in the future of the collaborative relationship. Chow, Cheung and Wa (2015:1) also state that where parties to a relationship illustrate a caring interest towards the goodwill of the other party, the chance of withdrawal from the relationship is lowered.

Commitment also influences satisfaction directly. The primary reason for this is that commitment is illustrated by being pre-emptive in the taking of steps to both initiate and sustain a relationship. In this way, both parties to the relationship will experience higher levels of satisfaction. This argument is supported by Farrellya and Quester (2005:212) and Nyaga et al. (2010:102-103) who state that commitment is an important element of a relationship to secure a positive relationship outcome. Business managers, therefore, need to take greater cognisance of the importance of commitment in securing and increasing satisfaction. Managers can specifically enhance satisfaction levels by being willing to make adjustments to suit the needs of the business relations; being willing to offer personalised services to meet the needs of the other party and displaying flexibility towards the other in the delivery of services.

From the results of this study, it should be noted that satisfaction should be perceived only as a pointer towards prospective cooperation, coordination and continuity. This is a further illustration of the importance of building sound B2B relationships to secure increased business success. Brito et al. (2014:953) refer to collaboration as a cooperative approach between business partners to attain mutually agreed goals. To achieve such collaboration there has to be a positive cooperative attitude between the manufacturer and the supplier. It is therefore imperative to note that the nurturing of such a positive cooperative attitude is vital because of the powerful 
association between attitude and behaviour. Therefore, when the parties in a B2B relationship are working together, it illustrates confirmation of coordination. To strengthen cooperation, there has to be a joint agreement between business partners on implementation plans, and processes and/or procedures are coordinated between the manufacturer and the supplier. Cheng and Tang (2014:379) concur with this finding by stating that increased coordination will enhance the level of understanding between parties, resulting in a stronger, market-oriented relationship. It remains important, however, for business managers to note that coordination is not always an outcome of cooperation. Finally, this study established that a positive relationship exists between satisfaction in B2B relations and the relationship continuity. A long-term relationship orientation can be achieved by securing customer satisfaction. Therefore, if any of the partners in a B2B relationship (such as a manufacturer-supplier relationship) becomes dissatisfied, it will result in the dissolution of the relationship with no recourse for future continuation. In conclusion, parties to a B2B relationship should develop relational plans that will secure an approach of inclusivity and collaboration. Engagement between all parties in a B2B relationship must be the starting point in the establishment and management of the relationship-building process.

\section{Conclusions, research limitations and future research}

The study investigated the interrelationship of different relational constructs of a conceptualised B2B relationship. The relationship model reflects the constructs of trust and commitment as positive precursors to the variable satisfaction. In addition, satisfaction is posited as a positive precursor to the variables coordination, cooperation and continuity. The findings of the study illustrate satisfactory fits between the different relational constructs and the proposed B2B model, as well as satisfactory reliability and validity for this purpose. In addition, all the hypotheses formulated for the study and tested through the proposed B2B model were supported by the results.

The study applied the use of a convenience sample to select the companies used in the study. The implication of this is that the findings obtained cannot be generalised to other large companies in the country of study or companies operating in different countries globally. Another limitation is that the study did not focus on all the different types of B2B relationships; only relationships between large companies and their suppliers in South Africa were tested. In addition, it is also important to note that the study explored the applied constructs (trust, commitment, satisfaction, cooperation, coordination and continuity) only from the viewpoint of the buyer. The limitation that results from this is that suppliers and buyers may perceive their level of relational trust, commitment and satisfaction towards each other differently. Emanating from the limitations are opportunities for further research. Firstly, the study on B2B relationships can be replicated in other emerging or developed economies of the world. Secondly, a broader spectrum of supplier and buyer types can be included in the study (e.g. companies of different sizes). Thirdly, a further suggestion for research in B2B relationships is to assess contending models that encompass different relationship marketing aspects of satisfaction, trust and commitment, with these aspects reflecting different relational outcomes over a wide contextual range. This type of research could strengthen the research focus in the field of relationship marketing. This could be achieved through a better understanding of how to enhance the positioning of relationship quality constructs to secure improved relational building outcomes.

Finally, the contribution made by the study is twofold. The theoretical nature of the contribution is that the study provides a robust argument based on the testing of the relational constructs in the theoretical model. This argument can be of benefit to other services where marketing researchers want to test the interrelationship of the different relational variables from an emerging economy perspective, especially considering that this study was conducted amongst the largest South African companies. In both the original study and the replicated study, it is evident that trust and commitment influence levels of satisfaction, which in turn influences coordination, cooperation and continuity. It is furthermore important for the management of a business setting to understand that satisfaction may be the outcome (rather than a precursor) of activities to establish trust and commitment in a supplier-buyer relationship. Satisfaction also underwrites three important elements of the relationship management process: coordination, cooperation and continuity. These three elements are therefore perceived as outcomes of a successful relationship. The practical nature of the contribution is through the empirical findings of the study. These findings clearly state that for suppliers to strengthen the satisfaction experience of their buyers (i.e. to make the satisfaction experience more positive), there has to be a greater focus on the establishment of both trust and commitment. Both variables, not just the one, are important in ensuring a positive satisfaction experience in a supplier-buyer relationship. The ability of a supplier to reduce marketing costs and secure a viable and stable customer grouping will depend on its ability to have greater knowledge of the different elements that strengthen positive conduct (inclusive of coordination, cooperation and continuity).

\section{Acknowledgements}

The Faculty of Management at the University of Johannesburg is acknowledged for the provision of funding for data collection.

\section{Competing interests}

The authors declare that they have no financial or personal relationships that may have inappropriately influenced them in writing this article.

\section{Authors' contributions}

M.R-L. was responsible for the conceptualisation of the problem, the development of the theoretical argument and the formulation of managerial implications. G.S. was responsible for the data analysis and M.M was responsible for the write up of the results. 


\section{References}

Akman, G. \& Yörür, B., 2012, 'Effects of business to business relations on customer satisfaction and loyalty in the context of a developing country', American Journal of Industrial and Business Management 2, 217-229. https://doi.org/10.4236/ ajibm.2012.24028

Altinay, L., Brookes, M., Madanoglu, M. \& Aktas, G., 2014, 'Franchisees' trust in and satisfaction with franchise partnerships', Journal of Business Research 67, 722728. https://doi.org/10.1016/j.jbusres.2013.11.034

Andaleeb, S., 1996, 'An experimental investigation of satisfaction and commitment in marketing channels: The role of trust and dependence', Journal of Retailing 72(1), 77-93. https://doi.org/10.1016/S0022-4359(96)90006-8

Anderson, E. \& Weitz, B., 1992, 'The use of pledges to build and sustain commitment in distribution channels', Journal of Marketing Research 29, 18-34. https://doi. org/10.2307/3172490

Anderson, J.C. \& Narus, J.A., 1990, 'A model of distributer firm and manufacturer firm working partnerships', Journal of Marketing 48, 62-74. https://doi. org/10.2307/1251511

Ashnai, B., Smirnova, M., Kouchtch, S., Yu, Q., Barnes, B.R. \& Naudé, P., 2009 'Assessing relationship quality in four business-to-business markets', Marketing Intelligence \& Planning 27(1), 86-102. https://doi.org/10.1108/02634500 Intelligence
910928353

Ata, U.Z. \& Toker, A., 2012, 'The effect of customer relationship management adoption in business-to-business markets', Journal of Business \& Industrial Marketing 27(6), 497-507. https://doi.org/10.1108/08858621211251497

Ballantyne, D., 2003, 'A relationship-mediated theory of internal marketing', European Journal of Marketing 37(9), 1242-1260. https://doi.org/10.1108/030905 60310486979

Bejou, D., Ennew, C.T. \& Palmer, A., 1998, 'Trust, ethics, and relationship satisfaction', International Journal of Bank Marketing 16(4), 170-175. https://doi. org/10.1108/02652329810220729

Biggemann, S. \& Buttle, F., 2009, 'Coordinated interaction and paradox in business relationships', Journal of Business \& Industrial Marketing 24(8), 549-560. https:// doi.org/10.1108/08858620910999420

Bojei, J. \& Abu, M.L., 2014, 'The underlying dimensions of relationship marketing in the Malaysian mobile service sector', Journal of Relationship Marketing 13(3), 169-190. https://doi.org/10.1080/15332667.2014.939017

Bowden-Everson, J.L.-H., Dagger, T. \& Elliot, G., 2013, 'Engaging customers for loyalty in the restaurant industry: The role of satisfaction, trust, and delight', Journal of Foodservice Business Research 16, 52-75. https://doi.org/10.1080/15378020.201 3.761025

Bowen, J.T. \& McCain, S.-L.C., 2015, 'Transitioning loyalty programs - A commentary on the relationship between customer loyalty and customer satisfaction', International Journal of Contemporary Hospitality Management 27(3), 415-430. https://doi.org/10.1108/IJCHM-07-2014-0368

Brito, L.A.L., Brito, E.P.Z. \& Hashiba, L.H., 2014, 'What type of cooperation with suppliers and customers leads to superior performance?', Journal of Business Research 67, 952-959. https://doi.org/10.1016/j.jbusres.2013.07.015

Brodie, R.J., 2017, 'Enhancing theory development in the domain of relationship marketing: How to avoid the danger of getting stuck in the middle', Journal of Services Marketing 31(1), 20-23. https://doi.org/10.1108/JSM-05-2016-0179

Campbell, D., 1955, 'The informant in quantitative research', American Journal of Sociology 60(3), 339-342. https://doi.org/10.1086/221565

Chang, H.-H., Tsai, Y.-C., Chen, S.-H., Huang, G.-H. \& Tseng, Y.-H., 2015, 'Building longterm partnerships by certificate implementation: A social exchange theory perspective', Journal of Business \& Industrial Marketing 30(7), 867-879. https:// perspective', Journal of Business \& Ind
doi.org/10.1108/JBIM-08-2013-0190

Chang, S., Wang, K., Chih, W. \& Tsai, W., 2012, 'Building customer commitment in business-to-business markets', Industrial Marketing Management 41, 940-950. https://doi.org/10.1016/j.indmarman.2011.11.026

Chang, T.-C. \& Chuang, S.-H., 2016, 'Exploring value of e-service innovation: Eservice and co-operation complementarity', in 10th International Conference on Innovative Mobile and Internet Services in Ubiquitous Computing, Fukuoka Institute of Technology (FIT), Fukuoka, Japan, July 6-8, 2016, n.p.

Che, M. \& Salleh, M., 2016, 'The significant contribution of Islamic relationship marketing practice in Malaysian Takaful industry towards determining customer gratitude, trust and commitment', Asian Academy of Management Journal 21(1), 171-207.

Chen, S. \& Choi, C.-J., 2005, 'A social exchange perspective on business ethics: An application to knowledge exchange', Journal of Business Ethics 62, 1-11. https:// doi.org/10.1007/s10551-005-7056-y

Cheng, J.-C., Chen, C.-Y., Yen, C.-H. \& Teng, H.-Y., 2017, 'Building customer satisfaction with tour leaders: The roles of customer trust, justice perception, and cooperation in group package tours', Asia Pacific Journal of Tourism Research 22(4), 395-407. https://doi.org/10.1080/10941665.2016.1271816

Cheng, J.-H. \& Tang, C.-H., 2014, 'Interorganizational cooperation and supply chain performance in the context of third party logistics services', Asia Pacific Management Review 19(4), 375-390.

Chisnall, P., 2005, Marketing research, 7th edn., McGraw-Hill Education (UK), New York.

Chiu, W., Kwag, M.-S. \& Bae, J.-S., 2015, 'Customers as partial employees: The influences of satisfaction and commitment on customer citizenship behavior in fitness centers', Journal of Physical Education and Sport 15(4), 627-633.
Chow, P.T., Cheung, S.O. \& Wa, Y.K., 2015, 'Impact of trust and satisfaction on the commitment-withdrawal relationship', Journal of Management Engineering 31(5), 1. https://doi.org/10.1061/(ASCE)ME.1943-5479.0000331

Churchill, G.A., Jr., 1979, 'A paradigm for developing better measures of marketing constructs', Journal of Marketing Research 16, 64-73. https://doi.org/ $10.2307 / 3150876$

Clampit, J., Kedia, B., Fabian, F. \& Gaffney, N., 2015, 'Offshoring satisfaction: The role of partnership credibility and cultural complementarity', Journal of World Business 50, 79-93. https://doi.org/10.1016/j.jwb.2014.02.001

Crain, D.W. \& Abraham, S., 2008, 'Using value-chain analysis to discover customers' strategic needs', Strategy \& Leadership Journal 36(4), 29-39. https://doi. org/10.1108/10878570810888759

Dai, H., Haried, P. \& Salam, A.F., 2011, 'Antecedents of online service quality, commitment and loyalty', Journal of Computer Information Systems 52(2), 1-11.

Denga, Z., Lua, Y., Weib, K.K. \& Zhanga, J., 2010, 'Understanding customer satisfaction and loyalty: An empirical study of mobile instant messages in China', Internationa Journal of Information Management 30, 289-300. https://doi.org/10.1016/j. Journal of Information

Espejel, J., Fandos, C. \& Flavián, C., 2011, 'Antecedents of consumer commitment to a PDO wine: An empirical analysis of Spanish consumers', Journal of Wine Research 22(3), 205-225. https://doi.org/10.1080/09571264.2011.622516

Evensen, K.B. \& Hansen, H., 2016, 'Cooperation and information sharing in institutional food chains', British Food Journal 118(10), 2388-2403. https://doi.org/10.1108/ BFJ-01-2016-0011

Fang, Y., Qureshi, I., Sun, H., McCole, P., Ramsey, E. \& Lim, K.H., 2014, 'Trust, satisfaction, and online repurchase intention: The moderating role of perceived effectiveness of e-commerce institutional mechanisms', MIS Quarterly 38(2), 407-424.

Farrelly, F.J. \& Quester, P.G., 2005, 'Examining important relationship quality constructs of the focal sponsorship exchange', Industrial Marketing Management 34(3), 211. https://doi.org/10.1016/j.indmarman.2004.09.003

Faryabi, M., Sadeghzadeh, K. \& Zakeri, A., 2015, 'The relationship continuity model and customer loyalty in the banking industry: A case study of the Maskan Bank of Iran', Journal of Relationship Marketing 14(1), 37-52. https://doi.org/10.1080/15 332667.2015.1006018

Fullerton, G., 2011, 'Creating advocates: The roles of satisfaction, trust and commitment', Journal of Retailing and Consumer Services 18(1), 92-100. https:// doi.org/10.1016/j.jretconser.2010.10.003

Garbarino, E. \& Johnson, M.S., 1999, 'The different roles of satisfaction, trust, and commitment in customer relationships', Journal of Marketing 63(2), 70-87. commitment in customer relationst
https://doi.org/10.2307/1251946

Gaurav, K., 2016, 'Impact of relationship marketing on customer loyalty: Evidence from Indian automobile industry', SMSVaranasi IX(1), 1-17.

Geyskens, I., Steenkamp, J.E.M. \& Kumar, N., 1999, 'A meta-analysis of satisfaction in marketing channel relationships', Journal of Marketing Research 26, 223-238. https://doi.org/10.2307/3152095

Gounaris, S.P., 2005, 'Trust and commitment influences on customer retention: Insights from business-to-business services', Journal of Business Research 58(2) 126-140. https://doi.org/10.1016/S0148-2963(03)00122-X

Grönroos, C., 1994, 'From marketing mix to relationship marketing: Towards a paradigm shift in marketing', Management Decision 32(2), 4-20. https://doi. org/10.1108/00251749410054774

Grönroos, C., 2006, 'A crisis in marketing', Business Review 8, 38-41.

Guiltinan, J.P., Rejab, I.B. \& Rodgers, W.C., 1980, 'Factors influencing coordination in a franchise channel', Journal of Retail 56(3), 41-58.

Gummesson, E., Kuusela, H. \& Närvänen, E., 2014, 'Reinventing marketing strategy by recasting supplier/customer roles', Journal of Service Management 25(2), 228240. https://doi.org/10.1108/JOSM-01-2014-0031

Hair, J.F., Black, W.C., Babin, B.J. \& Anderson, R., 2010, Multivariate data analysis: A global perspective, Pearson Education, Upper Saddle River, NJ.

Hair, J.F., Black, W.C., Babin, B.J., Anderson, R.E. \& Tatham, R.L., 2006, Multivariate data analysis, 6th edn., Prentice-Hall, Upper Saddle River, NJ.

Hair, J.F., Wolfinbarger Celsi, M., Money, A.H., Samouel, P. \& Page, M.J., 2011 Essentials of business research methods, ME Sharpe. Inc., New York.

Han, H. \& Hyun, S.S., 2015, 'Customer retention in the medical tourism industry: Impact of quality, satisfaction, trust, and price reasonableness', Tourism Management 46, 20-29. https://doi.org/10.1016/j.tourman.2014.06.003

Hansen, M.H., Morrow, J.L. \& Batista, J.C., 2002, 'The impact of trust on cooperative membership retention, performance and satisfaction: An exploratory study', International Food and Agribusiness Management Review 5, 41-59. https://doi. org/10.1016/S1096-7508(02)00069-1

Harker, M.J. \& Egan, J., 2006, 'The past, present and future of relationship marketing', Journal of Marketing Management 22(1/2), 215-242. https://doi.org/ $10.1362 / 026725706776022326$

Hartmann, H., Klink, J. \& Simons, J., 2015, 'Cause related marketing in the German retail sector: Exploring the role of consumers' trust', Food Policy 52, 108-114. https://doi.org/10.1016/j.foodpol.2014.06.012

Hasche, N., Linton, G. \& Öberg, C., 2017, 'Trust in open innovation - The case of a medtech start-up', European Journal of Innovation Management 20(1), 31-49. https://doi.org/10.1108/EJIM-10-2015-0111

Hau, L. \& Ngo, L., 2012, 'Relationship marketing in Vietnam: An empirical study', Asio Pacific Journal of Marketing and Logistics 24(2), 222-235. https://doi.org/ 10.1108/13555851211218039 
Heide, J.B. \& John, G., 1988, 'The role of dependence balancing in safeguarding transaction-specific assets in conventional channels', Journal of Marketing 52, tr-35. https://doi.org/10.2307/1251683

Hess, J., Story, J. \& Danes, J., 2011, 'A three-stage model of consumer relationship investment', Journal of Product \& Brand Management 20(1), 14-26. https://doi. org/10.1108/10610421111107987

Hong, I.B. \& Cho, H., 2011, 'The impact of consumer trust on attitudinal loyalty and purchase intentions in B2C e-marketplaces: Intermediary trust vs. seller trust', International Journal of Information Management 31, 469-479. https://doi. org/10.1016/j.ijinfomgt.2011.02.001

Hu, G., Wu, B. \& Chen, J., 2013, 'Dynamic adaptation of business process based on context changes: A rule-oriented approach', in International Conference on Service-Oriented Computing, pp. 492-504, Springer International Publishing, Berlin, German, December 2-5.

Human, G. \& Naudé, P., 2014, 'Heterogeneity in the quality-satisfaction-loyalty framework', Industrial Marketing Management 43, 920-928. https://doi. org/10.1016/j.indmarman.2014.05.006

Hung, S.-W., Cheng, M.-J. \& Chen, P.C., 2012, 'Reexamining the factors for trust in cultivating online customer repurchase intentions: The moderating effect of perceived waiting', International Journal of Human-Computer Interaction 28 666-677. https://doi.org/10.1080/10447318.2011.654201

Izogo, E.E., 2016, 'Structural equation test of relationship quality repurchase intention -Willingness to recommend framework in retail banking', International Journal of Emerging Markets 11(3), 374-394. https://doi.org/10.1108/IJOEM-07-2015-0130

Jarratt, D. \& Ceric, A., 2015, 'The complexity of trust in business collaborations', Australasian Marketing Journal 23, 2-12. https://doi.org/10.1016/j.ausmj. 2014.10.002

Jiang, Z., Henneberg, S.C. \& Naudé, P., 2011, 'Supplier relationship management in the construction industry: The effects of trust and dependence', Journal of Business \& Industrial Marketing 27(1), 3-15. https://doi.org/10.1108/08858621211188920

Johnson, M.S., Sividas, E. \& Garbarino, E., 2008, 'Customer satisfaction, perceived risk and effective commitment', Journal of Services Marketing 22(5), 353-362. https:// doi.org/10.1108/08876040810889120

Jöreskog, K.G. \& Sörbom, D., 1976, LISREL III: Estimation of linear structural equations systems by maximum likelihood methods, National Educational Resources, Chicago, IL.

Jumaev, M., Kumar, D. \& Hanaysha, R.M., 2012, 'Impact of relationship marketing on customer loyalty in the banking sector', Far East Research Centre 6(3), 36-55.

Kashif, M., Shukran, S.S.W., Rehman, M.A. \& Sarifuddin, S., 2015, 'Customer satisfaction and loyalty in Malaysian Islamic banks: A PAKSERV investigation' International Journal of Bank Marketing 33(1), 23-40. https://doi.org/10.1108/ IJBM-08-2013-0084

Kaur, G., Sharma, R.D. \& Mahajan, N., 2012, 'Exploring customer switching intentions through relationship marketing paradigm', International Journal of Bank Marketing 30(4), 280-302. https://doi.org/10.1108/02652321211236914

Keung, Y.-H., Shing, M-S., Alison, C.L.F. \& Hon, C.S., 2015, 'Case study: Co-operation, coordination and specific assets in inter-organisational relationships in Hong Kong's engineering firms', Advances in Management 8(12), 1.

Kim, J.-G., 2014, 'Applying service profit chain model to the Korean restaurant industry', International Journal of Hospitality Management 36, 1-13. https://doi. org/10.1016/j.ijhm.2013.07.008

Knox, S. \& Gruar, C., 2007, 'The application of stakeholder theory to relationship marketing strategy development in a non-profit organization', Journal of Business Ethics 75, 115-135. https://doi.org/10.1007/s10551-006-9258-3

Kuhn, S. \& Mostert, P., 2016, 'Relationship intention as a predictor of clothing retail customer's satisfaction, trust, commitment and relationship quality', Management Dynamics 25(1), 16-31.

Kundu, S. \& Datta, S.K., 2015, 'Impact of trust on the relationship of e-service quality and customer satisfaction', EuroMed Journal of Business 10(1), 21-46. https://doi. org/10.1108/EMJB-10-2013-0053

Laeequddin, M., Sahay, B.S., Sahay, V. \& Waheed, K.A., 2012, 'Trust building in supply chain partners relationship: An integrated conceptual model', Journal of Management Development 31(6), 550-564. https://doi.org/10.1108/02621 711211230858

Laeequddin, M. \& Sardana, G.D., 2010, 'What breaks trust in customer supplier relationship?', Management Decision 48(3), 353-365.

Lages, L.F., Lancastre, A. \& Lages, C., 2008, 'The B2B-RELPERF scale and scorecard: Bringing relationship marketing theory into business-to-business practice',
Industrial Marketing Management 37(6), 686-697. https://doi.org/10.1016/j. Industrial Marketing Monarman.2007.05.008

Lamprinopoulou, C. \& Tregear, A., 2011, 'Inter-firm relations in SME clusters and the link to marketing performance', Journal of Business \& Industrial Marketing 26(6), 421-429. https://doi.org/10.1108/08858621111156412

Lawler, E.J., 2001, 'An affect theory of social exchange', American Journal of Sociology 107(2), 321-352. https://doi.org/10.1086/324071

Leahy, R., 2011, 'Relationships in fast moving consumer goods markets-the consumers' perspective', European Journal of Marketing 45(4), 651-672. https://doi. org/10.1108/03090561111111370

Lioukas, C.S. \& Reuer, J.J., 2015, 'Isolating trust outcomes from exchange relationships: Social exchange and learning benefits of prior ties in alliances', Academy of Management Journal 58(6), 1826-1847. https://doi.org/10.5465/amj.2011.0934

Liu, Z., Min, Q., Zhai, Q. \& Smyth, R., 2016, 'Self-disclosure in Chinese micro-blogging: A social exchange theory perspective', Information \& Management 53, 53-63. https://doi.org/10.1016/j.im.2015.08.006
Lui, S.S., Wong, Y. \& Liu, W., 2009, 'Asset specificity in roles in interim cooperation: Reducing opportunistic behaviour or increasing cooperative behaviour', Journal of Reducing opportunistic behaviour or increasing cooperative behaviour', Journal of
Business Research 62, 1214-1219. https://doi.org/10.1016/j.jbusres.2008.08.003

Lusch, R.F. \& Brown, J.R., 1996, 'Interdependency, contracting, and relational behavior in marketing channels', Journal of Marketing 60, 19-38. https://doi.org/ $10.2307 / 1251899$

Macintosh, G., 2002, 'Building trust and satisfaction in travel counsellor/client relationships', Journal of Travel \& Tourism Marketing 12(4), 59-74. https://doi. org/10.1300/J073v12n04_04

Malhotra, N., Uslay, C. \& Ndubisi, O., 2008, 'Commentary on "the essence of business marketing theory, research and tactics: Contributions by the journal of businessto-business marketing," by Lichtenthal, Mummalaneni, and Wilson: A paradigm shift and prospection through expanded roles of buyers and sellers', Journal of Business-to-Business Marketing 15(2), 204-217. https://doi.org/10.1080/ 15470620802026157

Mohr, J., Fisher, R.J. \& Nevin, J.R., 1996, 'Collaborative communication in interfirm relationships: Moderating effects of integration and control', Journal of Marketing 60(3), 103-115. https://doi.org/10.2307/1251844

Mohr, J. \& Spekman, R., 1994, 'Characteristics of partnership success: Partnership attributes, communication behavior, and conflict resolution techniques', Strategic Management Journal 15, 135-152. https://doi.org/10.1002/smj.4250150205

Morgan, R. \& Hunt, S., 1994, 'The commitment-trust theory of relationship marketing', Journal of Marketing 58(3), 20-38. https://doi.org/10.2307/1252308

Naumann, E., Williams, P. \& Sajid Khan, M., 2009, 'Customer satisfaction and loyalty in B2B services: Directions for future research', The Marketing Review 9(4), 319-333. https://doi.org/10.1362/146934709X479908

Ndubisi, N.O., 2009, 'Business-to-business relationship marketing and ethical values: The mediation effect of commitment', Proceedings of the Academy of Marketing Studies 14(2):28-35

Ndubisi, N.O., 2011, 'Conflict handling, trust and commitment in outsourcing relationship: A Chinese and Indian study', Industrial Marketing Management 40 109-117. https://doi.org/10.1016/j.indmarman.2010.09.015

Ndubisi, N.O., 2012, 'Relationship quality: Upshot of mindfulness-based marketing strategy in small organisations', International Journal of Quality \& Reliability Management 29(6), 626-641. https://doi.org/10.1108/02656711211245638

Ndubisi, N.O., Malhotra, N.K., Capel, C.M., Agarwal, J., Satkunasingam, E., Ndubisi, G.C. et al., 2016, 'Long-term oriented marketing relationships and ethical conduct in outsourcing sector', Psychology \& Marketing 33(5), 372-388.

Ndubisi, N.O. \& Nataraajan, R., 2016, 'Marketing relationships in the new millennium B2B sector', Psychology \& Marketing 33(4), 227-231. https://doi.org/10.1002/ mar.20871

Negi, R. \& Ketema, E., 2010, 'Relationship marketing and customer loyalty: The Ethiopian mobile communications perspective', International Journal of Marketing Management 5(1), 113-124.

$\mathrm{Ng}, \mathrm{E} ., 2012$, 'An empirical study on the success factors of supplier-distributor relationships', Contemporary Management Research 8(2), 161.

Nguyen, B. \& Mutum, D.S., 2012, 'A review of customer relationship management: Successes, advances, pitfalls and futures', Business Process Management Journal 18(3), 400-419. https://doi.org/10.1108/14637151211232614

Nicholson, J., Lindgreen, A. \& Kitchen, P., 2009, 'Spatial and temporal specificity and transferability', Qualitative Market Research: An International Journal 12(2), 187207. https://doi.org/10.1108/13522750910948789

Nyaga, G., Whipple, J. \& Lynch, D., 2010, 'Examining supply chain relationships: Do buyer and supplier perspectives on collaborative relationships differ?', Journal of Operations Management 28(2), 101-114.

Palmatier, R.W., Dant, R.P., Grewel, D. \& Evans, K.R., 2006, 'Factors influencing the effectiveness of relationship marketing: A meta-analysis', Journal of Marketing 70 136-153. https://doi.org/10.1509/jmkg.70.4.136

Parra, M.G., de Nalda, A.L., Santiago, G. \& Perles, M., 2011, 'Towards a more humanistic understanding of organizational trust', Journal of Management Development 30(6), 605-614. https://doi.org/10.1108/02621711111135206

Payan, J.M., 2007, 'A review and delineation of cooperation and coordination in marketing channels', European Business Review 19(3), 216-233. https://doi. org/10.1108/09555340710746473

Payan, J.N., Hair, J., Andersson, S. \& Awuah, G., 2016, 'The precursor role of cooperation, coordination, and relationship assets in a relationship model', Journal of Business-to-Business Marketing 23(1), 63-79. https://doi.org/10.1080/ 1051712X.2016.1148455

Perez, L., Whitelock, J. \& Florin, J., 2013, 'Learning about customers - Managing B2B alliances between small technology startups and industry leaders', European Journal of Marketing 47(3/4), 431-462.

Peter, J.P., 1979, 'Reliability: A review of psychometric basics and recent marketing practices', Journal of Marketing Research 16, 6-17. https://doi.org/10.2307/ 3150868

Purnasaria, H. \& Yuliandoa, H., 2015, 'How relationship quality on custome commitment influences positive e-WOM', Agriculture and Agricultural Science Procedia 3, 149-153. https://doi.org/10.1016/j.aaspro.2015.01.029

Rai, A.K. \& Medha, S., 2013, 'The antecedents of customer loyalty: An empirical investigation in life insurance context', Journal of Competitiveness 5(2), 139-163. https://doi.org/10.7441/joc.2013.02.10

Ramaseshan, B., Leslie, S.C. \& Jae, H., 2006, 'Power, satisfaction, and relationship commitment in Chinese store-tenant relationship and their impact on performance', Journal of Retailing 82(1), 63-70. https://doi.org/10.1016/j.jretai. 2005.11.004 
Rauyruen, P. \& Miller, K.E., 2007, 'Relationship quality as a predictor of B2B custome loyalty', Journal of Business Research 60, 21-31. https://doi.org/10.1016/j. jbusres.2005.11.006

Razzaque, M.A. \& Boon, T.G., 2003, 'Effects of dependence and trust on channe satisfaction, commitment and cooperation', Journal of Business-to-Business Marketing 10(4), 23-48. https://doi.org/10.1300/J033v10n04_02

Read, B., 2009, 'Top tips to build and keep customer loyalty with CRM', Customer Interaction Solutions 27(9), 26-28.

Richard, J.E. \& Zhang, A., 2012, 'Corporate image, loyalty, and commitment in the consumer travel industry', Journal of Marketing Management 28(5-6), 568-593.

Rodríguez-del-Bosque, I.R., Agudo, J.C. \& Gutiérrez, H.S.M., 2006, 'Determinants of economic and social satisfaction in manufacturer-distributor relationships' Industrial Marketing Management 35, 666-675. https://doi.org/10.1016/j. indmarman.2005.05.006

Rutherford, B., 2012, 'Building buyer commitment to the salesperson', Journal of Business Research 65, 960-967. https://doi.org/10.1016/j.jbusres.2011.05.001

Saini, Y., Bick, G. \& Abdulla, L., 2011, 'Consumer awareness and usage of Islamic banking products in South Africa', Southern African Journal of Economic and Management Sciences 14(3), 298-313. https://doi.org/10.4102/sajems.v14i3.193

Salleh, M.C.M., 2016, 'The significant contribution of Islamic relationship marketing practice in Malaysian takaful industry towards determining customer gratitude, trust, and commitment', Asian Academy of Management Journal 21(1), 171-207. https://doi.org/10.21315/aamj2016.21.supp.1.8

Samaha, S.A., Beck, J.T. \& Palmatier, R.W., 2014, 'The role of culture in international relationship marketing', Journal of Marketing 78(5), 78-98. https://doi. org $/ 10.1509 / \mathrm{jm} .13 .0185$

Samaha, S.A., Palmatier, R.W. \& Dant, R.P., 2011, 'Poisoning relationships: Perceived unfairness in channels of distribution', Journal of Marketing 99(75), 99-117. https://doi.org/10.1509/jmkg.75.3.99

Sanchez-Franco, M.J., 2009, 'The moderating effects of involvement on the relationships between satisfaction, trust and commitment in e-banking', Journal of Interactive Marketing 23, 247-258. https://doi.org/10.1016/j.intmar. 2009.04.007

Sarmento, M., Simões, C. \& Farhangmehr, M., 2015, 'Applying a relationship marketing perspective to B2B trade fairs: The role of socialization episodes', Industria Marketing Management 44, 131-141. https://doi.org/10.1016/j.indmarman. 2014.10.010

Segarra-Moliner, J.R., Moliner-Tena, M.A. \& Sánchez-Garcia, J., 2013, 'Relationship quality in business to business: A cross-cultural perspective from universities', Marketing Intelligence and Planning 31(3), 196-215. https://doi.org/ $10.1108 / 02634501311324573$

Seto'-Pamies, D., 2012, 'Customer loyalty to service providers: Examining the role of service quality, customer satisfaction and trust', Total Quality Management 23(11), 1257-1271. https://doi.org/10.1080/14783363.2012.669551

Shamdasani, P.M. \& Sheth, J.N., 1995, 'An experimental approach to investigating satisfaction and continuity in marketing alliances', European Journal of Marketing 29(4), 6-23. https://doi.org/10.1108/03090569510086620

Sheth, J.N. \& Parvatiyar, A., 1995, 'The evolution of relationship marketing', International Business Review 4(4), 397-418. https://doi.org/10.1016/09695931(95)00018-6

Sierra, J.J. \& McQuitty, S., 2005, 'Service providers and customers: Social exchange theory and service loyalty', Journal of Services Marketing 19(6), 392-400. https:// doi.org/10.1108/08876040510620166

Skarmeas, D., Katisikeas, C.S., Spyropoulou, S. \& Salehi-Sangari, E., 2008, 'Market and supplier characteristics driving distributor relationship quality in international marketing channels of industrial products', Industrial Marketing Management 37(1), 23-36. https://doi.org/10.1016/j.indmarman.2007.04.004

Skinner, S.J., Gassenheimer, J.B. \& Kelley, S.W., 1992, 'Cooperation in supplier-deale relations', Journal of Retailing 68(2), 174-193.

Stavros, C. \& Westberg, K., 2009, 'Using triangulation and multiple case studies toadvance relationship marketing theory', Qualitative Market Research: An International Journal 12(3), 307-320. https://doi.org/10.1108/1352275091 0963827

Stein, A.D., Smith, M.F. \& Lancioni, R.A., 2013, 'The development and diffusion of customer relationship management (CRM) intelligence in business-to-business environments', Industrial Marketing Management 42, 855-861. https://doi. org/10.1016/j.indmarman.2013.06.004

Sun, K. \& Kim D., 2013, 'Does customer satisfaction increase firm performance? An application of American Customer Satisfaction Index (ACSI)', International Journal of Hospitality Management 35, 68-77. https://doi.org/10.1016/j.ijhm.2013. 05.008
Sung, Y. \& Choi, S.M., 2010, “I won't leave you although you disappoint me": The interplay between satisfaction, investment, and alternatives in determining consumer-brand relationship commitment', Psychology \& Marketing 27(11) consumer-brand relationship commitment, $1050-1074$. https://doi.org/10.1002/mar.20373

Svensson, G., Mysen, T. \& Payan, J., 2010, 'Balancing the sequential logic of quality constructs in manufacturing-supplier relationships - Causes and outcomes', Journal of Business Research 63, 1209-1214. https://doi.org/10.1016/j.jbusres. 2009.10.019

Tanskanen, K., 2015, 'Who wins in a complex buyer-supplier relationship? A social exchange theory based dyadic study', International Journal of Operations \& Production Management 35(4), 577-603. https://doi.org/10.1108/IJOPM-102012-0432

Taylor, S.A., Leigh Anne Novak Donovan, L.-A.N. \& Ishida, C., 2014, 'Consumer trust and satisfaction in the formation of consumer loyalty intentions in transactional exchange: The case of a mass discount retailer', Journal of Relationship Marketing 13(2), 125-154.

Theron, E. \& Terblanche, N., 2009, 'Dimensions of relationship marketing in businessto-business financial services', International Journal of Market Research 52(3), 383-402.

Theron, E. \& Terblanche, N., 2010, 'Dimensions of relationship marketing in businessto-business financial services', International Journal of Market Research 52(3) 383-402. https://doi.org/10.2501/S1470785310201326

Theron, E., Terblanche, N. \& Boshoff, C., 2010, 'The antecedents of relationship commitment in the management of relationships in business-to-business (B2B) financial services', Journal of Marketing Management 24(9/10), 997-1010.

Theron, E., Terblanche, N. \& Boshoff, C., 2011, 'The antecedents of trust in businessto-business financial services', Journal of Business-to-Business Marketing 18(2), 188-213. https://doi.org/10.1080/1051712X.2010.499837

Theron, E., Terblanche, N. \& Boshoff, C., 2012, 'A managerial framework for relationship management in the business-to-business financial services industry', Management Dynamics 21(4), 31-52.

Trasorras, R., Weinstein, A. \& Abratt, R., 2009, 'Value, satisfaction, loyalty and retention in professional services', Marketing Intelligence \& Planning 27(5), 615632. https://doi.org/10.1108/02634500910977854

Ulaga, W. \& Eggert, A., 2006, 'Relationship value and relationship quality. Broadening the nomological network of business-to-business relationships', European Journal of Marketing 40(3/4), 311-327.

Vesel, P. \& Zabkar, V., 2010, 'Comprehension of relationship quality in the retai environment', Managing Service Quality 20(3), 213-235. https://doi.org/10.1108/ 09604521011041952

Voldnes, G., Grønhaug, K. \& Nilssen, F., 2012, 'Satisfaction in buyer-seller relationships - Influence of cultural differences', Industrial Marketing Management 41, 10811093. https://doi.org/10.1016/j.indmarman.2012.03.001

Wang, L., Law, R., Hung, K. \& Guillet, B.D., 2014, 'Consumer trust in tourism and hospitality: A review of the literature', Journal of Hospitality and Tourism Management 21, 1-9. https://doi.org/10.1016/j.jhtm.2014.01.001

Ward, C. \& Berno, T., 2011, 'Beyond social exchange theory: Attitudes toward tourists', Annals of Tourism Research 38(4), 1556-1569. https://doi.org/10.1016/j. annals.2011.02.005

Watkins, A. \& Hill, R.P., 2009, 'A simulation of business-to-business decision making in a relationship marketing context', Industrial Marketing Management 38, 9941005. https://doi.org/10.1016/j.indmarman.2008.06.002

Wilson, E.J. \& Nielson, C.C., 2001, 'Cooperation and continuity in strategic business relationships', Journal of Business-to-Business Marketing 8(1), 1-24. https://doi. org/10.1300/J033v08n01 01

Wong, A. \& Zhou, L., 2006, 'Determinants and outcomes of relationship quality: A conceptual model and empirical investigation', Journal of International Consumer Marketing 18(3), 81-105. https://doi.org/10.1300/J046v18n03_05

Woodside, A.G. \& Baxter, R., 2015, 'Imprinting, honeymooning, or maturing: Testing three theories of how interfirm social bonding impacts suppliers' allocations of resources to business customers', Australasian Marketing Journal 23, 96-106. https://doi.org/10.1016/j.ausmj.2015.04.004

Wu, X., Zhou, H. \& Wu, D., 2012, 'Commitment, satisfaction, and customer loyalty: A theoretical explanation of the "satisfaction trap"', The Service Industries Journa 32(11), 1759-1774. https://doi.org/10.1080/02642069.2010.550043

Yeung, M.C.H., Ramasamy, A.B., Chen, C. \& Paliwoda, L., 2013, 'Customer satisfaction and consumer expenditure in selected European countries', International Journa of Research in Marketing 30, 406-416. https://doi.org/10.1016/j.jiresmar. of Research

Zaheer, A., McEvily, B. \& Perrone, V., 1998, 'Does trust matter? Exploring the effects of inter-organizational and interpersonal trust on performance', Organization Science 9(2), 141-159. https://doi.org/10.1287/orsc.9.2.141 